Volume XII, No. 2, pp. 40-48, 2011

\title{
GRADUATE TO INDUSTRY SUPPLY CHAIN: POST-GRADUATION PERCEPTION OF THE VALUE OF EMBEDDING MARKETING CONCEPTS IN INFORMATION SCIENCE AND TECHNOLOGY COURSES
}

\author{
Barry B. Flachsbart, Missouri University of Science \& Technology, barryf@mst.edu \\ Cassandra C. Elrod, Missouri University of Science and Technology, cassa@mst.edu
}

\begin{abstract}
The Department of Business and Information Technology at the Missouri University of Science \& Technology (Missouri S\&T), formerly the University of Missouri - Rolla, focuses on providing students with both business and information technology skill sets, particularly in its Information Science and Technology degree program. Students take business courses in addition to their technical courses. An earlier paper described processes that incorporated business concepts (especially marketing) directly into the technical courses, with the expectation that this would meet employer desires and needs for new employees with a more rounded, holistic approach to business and information technology and that this would increase the ability of students to get jobs and would lead to employers seeking more such graduates, hence creating a supply chain. This paper describes a survey to test that hypothesis. The results showed some perceived increase in helping students to interview for and get jobs, but only a weak correlation with a "pull" effect for employers seeking more students with these skills.
\end{abstract}

Keywords: Information Science, Marketing, Business Concepts, Information Technology, Higher Education, Student Employability

\section{INTRODUCTION}

The "supply chain" between employment of graduating students and the recruitment of new students is critically important, especially when economic contractions occur. As in a typical supply chain scenario, potential students are "pulled" into specific curricula in large part based on the job success they observe among graduating students in that curricula -- i.e., how well graduates are being "pulled" into industry [8, 11]. Elrod, et al illustrated this in Fig. 1 $[2,3]$.

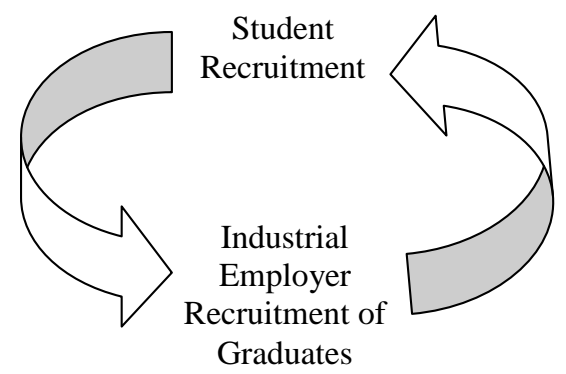

Figure 1: Cyclical Student to Industry Process

The area of job success for graduates who combine, in some way, business and marketing skills with technology skills has been considered by many authors. In particular, there has been recognition of the need for business and marketing students to understand and be able to use aspects of technology successfully in order to perform well in employment situations $[1,5,6,10,12]$. In addition, there have been clear descriptions of the need for managers to understand technology as well as business theory: "Employees with an understanding of both technology and business processes are ... valuable. A new position is being created ... [to work] as a liaison between the IT 
department and the non-IT employees who have a business problem to solve" [9]. When McBane [9] wrote this, he was thinking in terms of teaching technology to business and marketing students. Elrod, et. al. [3] looked at embedding marketing concepts (such as the importance of product, price, place, and promotion, as well as marketing strategy concepts to promote technology products and services) into technology courses, to create individuals with similar skills, but starting from a technology base. Others have noted that they were motivated by literature about insertion of technology topics into business and marketing courses [1, 5, 6, 9, 10, 12].

Previously, Elrod, et. al, [3] described degrees and curriculum offered by the Business and Information Technology Department (BIT) at Missouri University of Science and Technology (Missouri S\&T). These degrees and curriculum attempt to reflect industry demand, utilizing input from an Advisory Board of industry members, indepth interactions with recruiters at Missouri S\&T Career Fairs, and feedback from graduating seniors as they begin employment.

Four degrees are offered within the department:

- B.S. in Information Science and Technology

- B.S. in Business and Management Systems

- M.S. in Information Science and Technology

- Masters in Business Administration (MBA)

Each B.S. degree program for students in BIT includes a set of core courses from the other B.S. major, along with courses in the primary major and general studies courses required by the University for all B.S. students. Specifically, undergraduate students in Business and Management Systems focus primarily on business topics, but they also take two courses that expose them to computer programming concepts; a course that deals with management information systems, including an introduction to database concepts; and one course that explores the technology and use of Enterprise Resource Planning systems in a business environment.

Undergraduate students in Information Science and Technology focus primarily on the use and applications of computing systems, but they also take common business topic courses including management and organizational behavior, financial accounting, corporate finance, and marketing.

The MBA degree focuses in developing disciplined leaders who are focused on successful implementation and results for the workplace.

Graduate students in Information Science and Technology are required to take a Leadership in Technology-Based Organizations course, which involves extensive discussions of business topics for technology organizations. Some MBA students also take the course as an approved elective; undergraduates in either B.S. major may also take this course as an option.

Elrod, et. al. [3] further described two courses that were used to explore the concept of putting business and marketing concepts inside an information technology class. The first, Computer Internals and Operating Systems [4], is an undergraduate class required of all Information Science and Technology B.S. majors. The second, Leadership in Technology-Based Organizations [7], is a graduate class required of all Information Science and Technology M.S. majors. It also may be taken by advanced undergraduate students.

They believed that enhancing the skills of graduates in this way would lead to increased employment or to more value for employed individuals with these skills, but they did not include any evidence to validate that belief.

\section{RATIONALE FOR STUDY}

The purpose of this paper is to follow Information Science and Technology graduates who were exposed to the courses described above that included insertion of business and marketing principles and see if these graduates perceived value in their careers from the material inserted. If so, then the "pull" from industry would be stronger, 
Volume XII, No. 2, pp. 40-48, 2011

leading to increased and easier recruitment of new students into the Information Science \& Technology curriculum, hence strengthening the supply chain.

\section{METHODOLOGY}

A survey that asked specific questions of graduates from the courses was distributed to graduates for whom contact information was available. The survey contained statements that were designed to be answered following a standard 5-point Likert scale, with "5" being strongly agree and "1" being strongly disagree.

Each course was the subject of a separate set of statements. Respondents answered one or both sets, depending on the courses they had taken.

A copy of the survey used is shown in the Appendix, but Figure 2 abstracts the survey questions for rapid visualization.

\begin{tabular}{|l|l|l|}
\hline$\#$ & Abstraction & Actual Statement \\
\hline 1 & Application to work & $\begin{array}{l}\text { Knowing the business and marketing topics was valuable to } \\
\text { me in understanding how course concepts applied to work } \\
\text { situations. }\end{array}$ \\
\hline 2 & During Interviews & $\begin{array}{l}\text { Knowing the business and marketing topics was valuable to } \\
\text { me when I was interviewing for jobs. }\end{array}$ \\
\hline 3 & Getting First Job & $\begin{array}{l}\text { Knowing the business and marketing topics helped me } \\
\text { obtain my first job after graduation. }\end{array}$ \\
\hline 4 & Understanding Job Now & $\begin{array}{l}\text { Knowing the business and marketing topics is helpful to me } \\
\text { in understanding some aspects of my present job. }\end{array}$ \\
\hline 5 & Useful on Job Now & $\begin{array}{l}\text { Knowing the business and marketing topics is useful in my } \\
\text { job. }\end{array}$ \\
\hline 6 & Value to Employer & $\begin{array}{l}\text { The fact that I knew the business and marketing topics has } \\
\text { caused my employer to value me more highly. }\end{array}$ \\
\hline 7 & S\&T Benefit & $\begin{array}{l}\text { Knowing the business and marketing topics has caused my } \\
\text { employer to seek additional employees from Missouri S\&T. }\end{array}$ \\
\hline
\end{tabular}

Figure 2: Abstraction Of Survey Items

\section{RESULTS AND DISCUSSION}

The questionnaire was sent to approximately 85 graduates of the Information Science and Technology program. A response rate of approximately $14 \%$ was obtained, with 12 graduates completing the questionnaire. The overall results varied from statement to statement and between the two courses, but all responses except one were above a neutral 3.0. The strongest agreement was that the material learned was helpful to the employees in their work and that it had been helpful to them in interviewing for jobs. On the other hand, the weakest support was in considering whether the material had been helpful to them in getting their first job -- for the undergraduate course, more responses were negative than were positive on this point. But the results on this question for the undergraduate course were very bi-polar, with no responses being neutral -- the respondents either agreed or disagreed.

There was also general support for the help in understanding the job now and in being useful on the job. However, each course was deemed to be only slightly positive relative to the key question about whether employers were likely to seek additional employees from Missouri S\&T, indicating that the anticipated "pull" was weak, which is counter to the researchers' anticipation. Clearly, this seems to be an area where further study, and perhaps some questions directed to employers, would be helpful. 
Volume XII, No. 2, pp. 40-48, 2011

\section{Results For Course 1 - Computer Internals And Operating Systems}

Figure 3 shows the results for the seven statements.

\begin{tabular}{|l|l|c|c|c|c|}
\hline Statement & N & Minimum & Maximum & Mean & Std. Dev. \\
\hline Application to work & 10 & 3 & 5 & 4.00 & 0.82 \\
\hline During Interviews & 9 & 2 & 5 & 3.89 & 1.05 \\
\hline Getting First Job & 9 & 1 & 5 & 2.89 & 1.62 \\
\hline Understanding Job Now & 9 & 2 & 5 & 3.67 & 1.12 \\
\hline Useful on Job Now & 9 & 1 & 5 & 3.44 & 1.24 \\
\hline Value to Employer & 9 & 1 & 5 & 3.22 & 1.30 \\
\hline S\&T Benefit & 9 & 1 & 5 & 3.22 & 1.09 \\
\hline
\end{tabular}

Figure 3: Results For Course 1

The number of respondents for this section was very interesting, with one more response for the first question than for any of the others. The first question also received the strongest support, with no disagreement to the statement that the material was valuable in understanding work situations. Support was also relatively strong for the value of the material in interviewing and in understanding present work. Neither of these questions had any strong disagreement. The disagreement relative to the help in obtaining a first job was unexpected, as was the fact that all respondents were clearly in agreement or in disagreement (no choices of 3 on the scale) for that question.

\section{Results For Course 2 - Leadership In Technology-Based Organizations}

Figure 4 shows the results for the seven statements.

\begin{tabular}{|l|l|c|c|c|c|}
\hline Statement & $\mathbf{N}$ & Minimum & Maximum & Mean & Std. Dev. \\
\hline Application to work & 12 & 2 & 5 & 3.83 & 1.11 \\
\hline During Interviews & 12 & 1 & 5 & 3.58 & 1.24 \\
\hline Getting First Job & 11 & 2 & 5 & 3.27 & 1.10 \\
\hline Understanding Job Now & 12 & 1 & 5 & 3.75 & 1.14 \\
\hline Useful on Job Now & 12 & 2 & 5 & 3.92 & 0.79 \\
\hline Value to Employer & 12 & 2 & 5 & 3.42 & 1.08 \\
\hline S\&T Benefit & 11 & 1 & 5 & 3.18 & 0.98 \\
\hline
\end{tabular}

Figure 4: Results For Course 2

The upper level course showed stronger support for the material in general, with four of the seven questions turning up no strong disagreement and the mean values higher for the middle questions than had been shown in the undergraduate results. However, there was slightly less strong agreement to the first two questions and an even weaker response to the seventh question about employers hiring more graduates as a result of the knowledge displayed.

One possible explanation might be that these employees were being hired primarily for their strong technical skills and the benefits of broader skills might only show up later in their careers, beyond a time when the employers would be discussing recruiting with these employees. Questions to employers and to these employees later in their careers would be useful in exploring such a hypothesis. 
Volume XII, No. 2, pp. 40-48, 2011

\section{CONCLUSION}

Overall, marketing in Information Science and Technology courses seem to be valuable to graduates in obtaining jobs and understanding their work functions. With time, students seeking the Information Science and Technology courses at the Missouri University of Science and Technology will learn marketing concepts in technology courses, use the information in getting jobs and understanding their work functions, and create a "pull system" for this supply chain.

\section{ACKNOWLEDGMENT}

The authors want to acknowledge the assistance of Dr. William Kehr, Associate Teaching Professor at Missouri S\&T, who helped with the survey and with gathering email addresses of graduates.

\section{REFERENCES}

1. Benbunan-Fich, Raquel, Héctor R. Lozada, Stephen Pirog, Randi Priluck, and Joseph Wisenblit (2001), "Integrating Information Technology into the Marketing Curriculum: A Pragmatic Paradigm," Journal of Marketing Education. 23-1 (April), 5-15.

2. Elrod, Cassandra., C. (2007). The Development and Application of a Systematic Approach to Evaluating an Academic Department's Brand Meaning. Engineering Management \& Systems Engineering. Rolla, University of Missouri - Rolla. PhD: 87.

3. Elrod, Cassandra C., Flachsbart, Barry B., and Kehr, William, Improving Student Employability by Embedding Marketing Concepts in Technology Classes, Issues in Information Sciences, Volume X, No. 1, 2009.

4. Flachsbart, Barry. (2008). Information Science \& Technology 231 Course Notes \& Lectures, Missouri University of Science \& Technology.

5. Hannaford, William, Robert Erffmeyer, and Chuck Tomkovick (2002), "Championing Technology in Marketing Education: Assessing the Value of a Discipline-Specific Technology Course," Marketing Education Review, 12-3 (Fall), 47-57.

6. Hunt, Lynn, Lynne Eagle, and Phillip J. Kitchen (2004), "Balancing Marketing Education and Information Technology: Matching Needs or Needing a Better Match?" Journal of Marketing Education, 26-1 (April), 7588.

7. Kehr, William., R. (2008). Information Science \& Technology 351 Course Notes \& Lectures. Missouri University of Science \& Technology.

8. Lee, Hsu-Tung, \& Michael H. Wang (2008). "On the Search of Workstations Arrangement in Pull Production Systems." Computers \& Industrial Engineering 54(3): 613-623.

9. McBane, Donald (2003), "Getting the Horse to Drink: Teaching Technology to Marketing Students," Marketing Education Review, 13-2 (Summer), 1-6.

10. Miller, Fred, and W. Glynn Mangold (1996), "Developing Information Technology Skills in the Marketing Curriculum," Marketing Education Review, 6-1 (Spring), 29-39.

11. Najarian, Gerald (2008). "The Pull System Mystery Explained: Drum, Buffer \& Rope With a Computer." Retrieved 5/2/2008, 2008, from http://www.themanager.org/Strategy/Pull_System.htm.

12. Paul, Pallab and Kausiki Mukhopadhyay (2001), "Using Information Technology for Active Learning in International Business Education," Marketing Education Review, 11-3 (Fall), 81-89. 
Volume XII, No. 2, pp. 40-48, 2011

\section{APPENDIX}

Purpose: The purpose of this survey is to gather your input and opinion on how much, if any, the business and marketing topics inserted into IST 231 (Computing Internals and Operating Systems) and IST 351 (Leadership in Technology-Based Organizations) have impacted your job or career.

Which Sections To Respond To: Some of you may have taken both courses and some only one. Please answer the seven questions for each course that you took. The questions are only slightly different between the two courses.

Please note: you are confirming that you are over the age of 18 and are giving consent to participate in this survey when you proceed and complete the survey. Thank you!

You may find that a reminder of just what subject matter we are interested in will be convenient:

IST 231 (Computing Internals \& Operating Systems) We tried to bring in the need for considering business and marketing decisions as well as technical decisions. We noted that getting the technical details wrong can mess up business decisions and that making inappropriate business decisions can make the technology irrelevant. Some specific examples we talked about:

- Looking at technology decisions in terms of how they impact the marketing and promotion of a product, in addition to the cost and technical capabilities.

- Missing business opportunities by not realizing the possible uses of a technological innovation -- such as the PC (missed by Intel), the market for PC operating systems (missed by Gary Kildall, inventor of CPM), Ethernet (missed by Xerox), object-oriented programming (missed by Xerox), and a GUI-based OS (missed by Xerox).

- Understanding business opportunities can enable the exploitation of technical innovation -- such as the market for applications (exploited by Microsoft) and the market for self-contained PCs (exploited by Apple).

- The need for protecting software, illustrated by the failure of Bricklin and Frankstone to patent VisiCalc.

- The need to retain pricing power, illustrated by IBM's inability to make money from PCs due to the clone market.

- Knowing the business and marketing topics was valuable to me in understanding how course concepts applied to work situations. 
Volume XII, No. 2, pp. 40-48, 2011

O 1- Strongly Disagree

O 2 - Somewhat disagree

O 3 - Neither Agree or Disagree

O 4 - Somewhat Agree

O 5 - Strongly Agree

Knowing the business and marketing topics was valuable to me when I was interviewing for jobs.

O 1- Strongly Disagree

O 2 - Somewhat disagree

O 3 - Neither Agree or Disagree

O 4 - Somewhat Agree

O 5 - Strongly Agree

Knowing the business and marketing topics helped me obtain my first job after graduation.

O 1- Strongly Disagree

O 2 - Somewhat disagree

O 3 - Neither Agree or Disagree

O 4 - Somewhat Agree

O 5 - Strongly Agree

Knowing the business and marketing topics is helpful to me in understanding some aspects of my present job.

O 1- Strongly Disagree

O 2 - Somewhat disagree

O 3 - Neither Agree or Disagree

O 4 - Somewhat Agree

O 5 - Strongly Agree

Knowing the business and marketing topics is useful in my job.

O 1 - Strongly Disagree

O 2 - Somewhat Disagree

O 3 - Neither Agree or Disagree

O 4 - Somewhat Agree

O 5 - Strongly Agree

The fact that I knew the business and marketing topics has caused my employer to value me more highly.

O 1- Strongly Disagree

O 2 - Somewhat disagree

O 3 - Neither Agree or Disagree

O 4 - Somewhat Agree

O 5 - Strongly Agree

My knowledge of the business and marketing topics has caused my employer to seek additional employees from Missouri S\&T.

O 1- Strongly Disagree

O 2 - Somewhat disagree

O 3 - Neither Agree or Disagree

O 4 - Somewhat Agree

O 5 - Strongly Agree 
Volume XII, No. 2, pp. 40-48, 2011

IST 351 (Leadership in Technology-Based Organizations) Much of what we discussed outside of the textbook came from the world of marketing. The list below gives some of the marketing topics we talked about during class:

- Group problem-solving and seeking common goals is part of technology adoption in all cases. In organizations, the process is more formal, due to division of labor, levels of authority, and the number of people involved in the decision process.

- Continuous training, developing new competencies, and the aggressive use of alliances can all help companies capitalize on radical new technologies. These same technologies are often adopted by and benefit existing companies most, due to their existing infrastructure and customer base.

- Being able to gauge where a product is in its life cycle helps companies make better decisions about spending money on existing products or developing new products.

- Being the first company to bring a new product to market is virtually always an advantage. However, by employing new technologies to add features and fix problems with existing products, competitors can overcome the first mover's advantages. 
Knowing the marketing topics was valuable to me in understanding how course concepts applied to work situations.

O 1- Strongly Disagree

O 2 - Somewhat disagree

O 3 - Neither Agree or Disagree

O 4 - Somewhat Agree

O 5 - Strongly Agree

Knowing the marketing topics was valuable to me when I was interviewing for jobs.

O 1- Strongly Disagree

O 2 - Somewhat disagree

O 3 - Neither Agree or Disagree

O 4 - Somewhat Agree

O 5 - Strongly Agree

Knowing the marketing topics helped me obtain my first job after graduation.

O 1- Strongly Disagree

O 2 - Somewhat disagree

O 3 - Neither Agree or Disagree

O 4 - Somewhat Agree

O 5 - Strongly Agree

Knowing the marketing topics is helpful to me in understanding some aspects of my present job.

O 1- Strongly Disagree

O 2 - Somewhat disagree

O 3 - Neither Agree or Disagree

O 4 - Somewhat Agree

O 5 - Strongly Agree

Knowing the marketing topics is useful in my job.

O 1- Strongly Disagree

O 2 - Somewhat disagree

O 3 - Neither Agree or Disagree

O 4 - Somewhat Agree

O 5 - Strongly Agree

The fact that I knew the marketing topics has caused my employer to value me more highly.

O 1- Strongly Disagree

O 2 - Somewhat disagree

O 3 - Neither Agree or Disagree

O 4 - Somewhat Agree

O 5 - Strongly Agree

My knowledge of the marketing topics has caused my employer to seek additional employees from Missouri S\&T.

O 1- Strongly Disagree

O 2 - Somewhat disagree

O 3 - Neither Agree or Disagree

O 4 - Somewhat Agree

O 5 - Strongly Agree 